\title{
UNIDADES QUATERNÁRIAS E VEGETAÇÃO NATIVA DE PLANÍCIE COSTEIRA E BAIXA ENCOSTA DA SERRA DO MAR NO LITORAL NORTE DE SÃO PAULO
}

\author{
Celia Regina de Gouveia SOUZA \\ Graciele da Costa LUNA
}

\begin{abstract}
RESUMO
Na zona costeira do Estado de São Paulo, apesar das fortes pressões sócioeconômicas para a utilização de seus recursos e espaços naturais, ainda podem ser encontrados importantes remanescentes de Mata Atlântica e ecossistemas associados, principalmente no Litoral Norte. Estes ecossistemas incluem os manguezais e todas as demais vegetações presentes nas planícies costeiras e baixas encostas da Serra do Mar (vegetação de "restinga"), as quais são caracterizadas pela estreita relação que guardam com o substrato sedimentar que recobrem. Este trabalho apresenta os resultados de mapeamentos realizados no Litoral Norte de São Paulo e tem os seguintes objetivos: atualizar os mapas do Quaternário costeiro realizados na década de 1970, realizar o mapeamento pioneiro das fitofisionomias de "restinga" descritas na Resolução Conama no 07/1996, estabelecer as associações entre as Unidades Geológico-Geomorfológicas Quaternárias e essas fitofisionomias e calcular as porcentagens de supressão da vegetação nativa em relação à paisagem original na área de estudo.
\end{abstract}

Palavras-chave: unidades geológico-geomorfológicas quaternárias, fitofisionomias, associações, supressão da vegetação, planície costeira, Litoral Norte de São Paulo.

\section{ABSTRACT}

In spite of strong socio-economic pressures, important remains of Atlantic Forest and associated ecosystems may be found in the coastal zone of the State of São Paulo, mainly in its northern portion. These ecosystems include mangroves and all other types of vegetation that cover coastal plains and lower slopes of the Serra do Mar ("restinga" vegetation), whose principal characteristic is their very close relationship with sedimentary deposits. This paper presents results of mapping carried out along the Northern Littoral region of the State of São Paulo, whose main objectives were to update the available coastal Quaternary maps produced in the 1970s; carry out the first mapping of "restinga" phytophysiognomies based on federal environmental law; establish the association between the geologic-geomorphological Quaternary Units and these phytophysiognomies; and calculate the percentages of depletion of the original vegetation in the study area.

Keywords: geologic-geomorphological Quaternary units, phytophysiognomies, coastal plain, State of São Paulo Northern Littoral region

\section{INTRODUÇÃO}

Cerca de 5\% da população do Estado de São Paulo vive nos seus dezesseis municípios litorâneos (Figura 1), perfazendo quase 2.000 .000 de habitantes (SEADE 2008), número que se duplica nas férias e feriados prolongados.
Nas últimas décadas, a maioria dos municípios costeiros paulistas tem apresentado elevadas taxas de crescimento demográfico, muito acima da média estadual (1,34\% ao ano, entre 2000 e 2008), a exemplo de Bertioga (4,62\%), Ilha Comprida $(4,17 \%)$, Ilhabela (3,29\%), Mongaguá (3,04\%), Praia Grande (2,95\%), Itanhaém (2,85\%), Ubatuba 


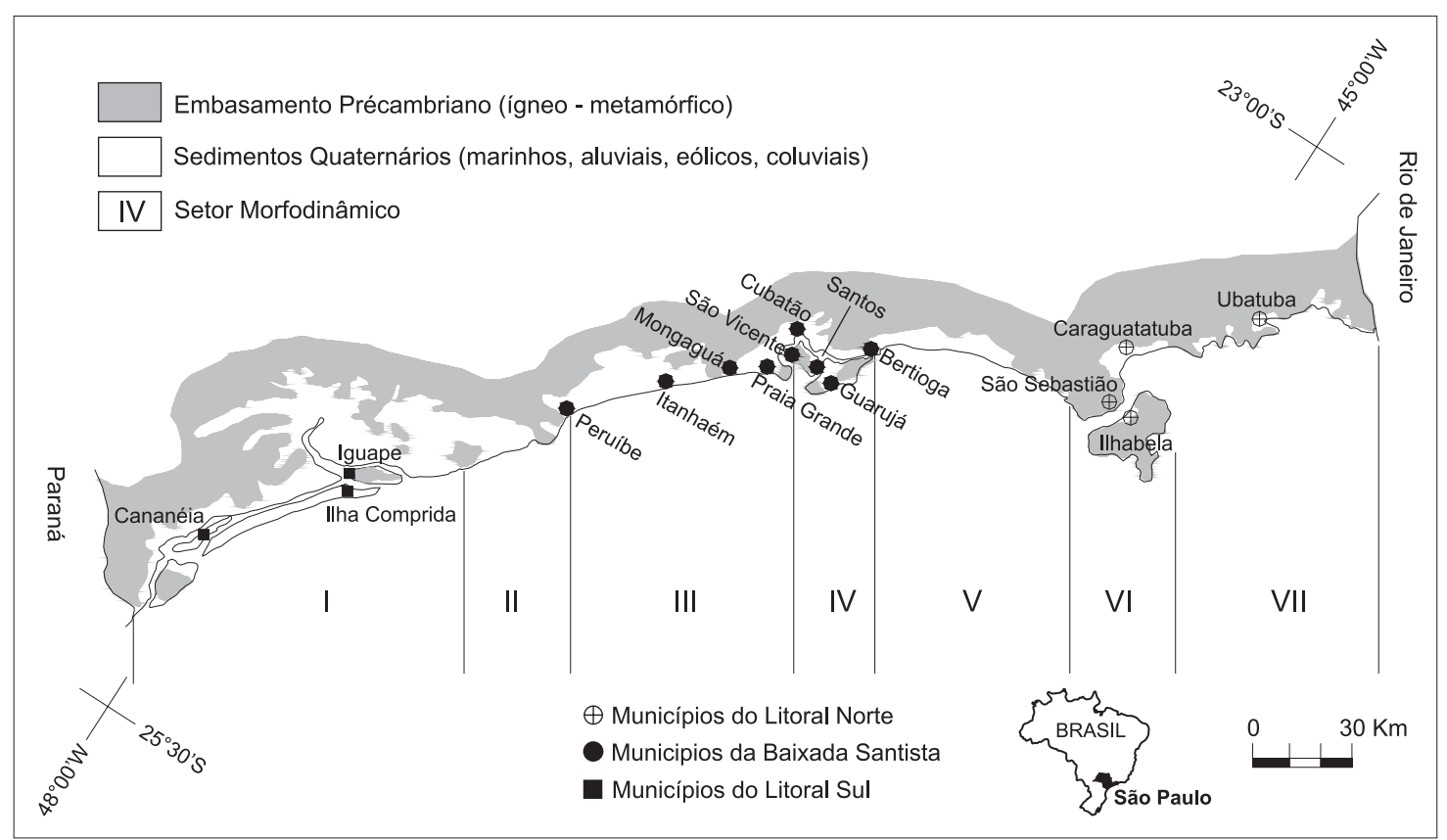

FIGURA 1 - Municípios litorâneos e compartimentação morfodinâmica do litoral paulista (SOUZA \& SUGUIO 1996).

$(2,67 \%)$ e São Sebastião $(2,39 \%)$. Os demais municípios cresceram a taxas entre $1,90 \%$ (Guarujá) e 0,38\% (Santos) ao ano (SEADE 2008).

As pressões sócio-econômicas decorrentes desse crescimento desencadearam um processo acelerado de degradação ambiental e outros impactos negativos (SOUZA et al. 2001). Como resultado, o litoral paulista apresenta vários problemas e conflitos ligados à utilização sustentável de seus recursos naturais, ao comprometimento da qualidade ambiental, ao desencadeamento e/ou aumento da freqüência e intensidade de perigos naturais e à resolução de questões institucionais (FILET et al. 2001, SOUZA 2003/2004). Esses problemas são ameaça à sustentabilidade econômica e à qualidade ambiental e de vida das populações humanas que ali habitam.

Apesar desse quadro, a zona costeira de São Paulo ainda guarda grande diversidade de ambientes naturais, evidenciados pela presença de extensos maciços preservados de Mata Atlântica e fragmentos de seus ecossistemas associados, estes representados por manguezais e diversas fitofisionomias que recobrem as planícies costeiras e as baixas a médias encostas da Serra do Mar. Os remanescentes desse bioma totalizam 13,24\% da cobertura original do Estado, dos quais 12,11\% correspondem às florestas da Mata Atlântica propriamente dita, $1,02 \%$ à vegetação de "Restinga" e $0,11 \%$ aos Manguezais (SOSMA/INPE 2008).
No Litoral Norte de São Paulo localizam-se as mais belas e concorridas paisagens costeiras do Estado. Em meados da década de 1970, com a construção da rodovia BR-101 interligando as cidades de Santos e do Rio de Janeiro, essa região passou a despertar grande interesse para a implantação de empreendimentos turísticos, incluindo condomínios de luxo, loteamentos de alto padrão e marinas (FILET et al. 2001). Além do turismo, outra importante atividade econômica desse setor costeiro é o Porto de São Sebastião, por onde circula parte da produção nacional e internacional de petróleo destinada ao maior terminal petrolífero da América Latina, o TEBAR, também localizado em São Sebastião. Atualmente, o Porto está em processo de expansão para atender à demanda crescente de escoamento dos produtos industriais do Vale do Paraíba e da produção de novas jazidas de petróleo e gás descobertas na Bacia de Santos (Campo de Mexilhão).

Tudo isso tem se refletido no estabelecimento de uma nova rota de migração de populações provenientes dos estados do Nordeste do Brasil e de Minas Gerais (SMA 1998) e nas altas taxas de crescimento populacional dos municípios, como comentado acima. O Litoral Norte apresenta taxa de crescimento anual de população de $2,34 \%$ ao ano e, dentre os seus quatro municípios, Caraguatatuba tem a menor taxa, com $1,75 \%$ ao ano, e Ilha- 
bela a maior (3,29\%) (SEADE 2008). Como dito anteriormente, Ubatuba apresentou taxa de crescimento de 2,67\% e São Sebastião de 2,39\% ao ano. Esse quadro, no entanto, deve se ampliar após a conclusão da expansão do Porto de São Sebastião e da implantação dos projetos da Petrobrás, que incluem obras (gasoduto e Usina de Tratamento Gás em Caraguatatuba) relacionadas à exploração do Campo de Mexilhão.

No Brasil, a vegetação das planícies costeiras tem sido genérica e inadequadamente denominada de "vegetação de restinga" (SOUZA 2006, SOUZA et al. 2008). A inadequação no uso do termo "restinga" deve-se principalmente a duas razões: (a) originalmente, a palavra foi introduzida para definir feições arenosas de linha de costa atuais e instáveis, como esporões ou pontais arenosos, barras arenosas e tômbolos (conceitos geológicos e geomorfológicos), mas com o passar do tempo foi sendo generalizada, por alguns autores, para se referir também a outros tipos de depósitos de origem marinha presentes nas planícies costeiras (cristas praiais ou cordões litorâneos regressivos e terraços marinhos), e mesmo a depósitos arenosos ou não, de outras origens; (b) da mesma forma, o termo também acabou sendo extrapolado para todas as fitofisionomias presentes nas planícies costeiras, que recobrem depósitos marinhos e não marinhos, e até as vegetações presentes nos corpos sedimentares das baixas a médias encostas da Serra do Mar(SOUZA et al. 2008).
Um exemplo disso está na Resolução Conama n 07/1996, que estabelece os parâmetros básicos para a análise dos estágios de sucessão da "vegetação de restinga" no Estado de São Paulo (regulamenta o artigo $6^{\circ}$ do Decreto Federal no $750 / 1993$ ). Essa resolução foi elaborada por um grupo de especialistas, a partir da compilação de estudos realizados em algumas áreas do Litoral Sul e do Litoral Norte de São Paulo (BENDAZOLLI et al. 1996).

Por causa dos problemas conceituas que envolvem o termo "restinga", SOUZA (2006) propôs a re-denominação dessa vegetação para "vegetação de planície costeira e baixa-média encosta" (exceto manguezal).

Uma característica importante dessas fitofisionomias é a sua dependência em relação à natureza do solo, sendo durante muito tempo consideradas comunidades edáficas (e.g. RIZZINI 1963). Mais recentemente, tendo como base estudos realizados em Bertioga, SOUZA et al. $(2007,2009)$ se referiram a elas como comunidades geo-pedológicas, por dependerem mais da natureza e da evolução do substrato geológico e de suas características pedológicas (tipo e evolução dos solos).

Entretanto, cerca de dez anos antes, SOUZA et al. (1997) já haviam observado a existência de associações importantes entre o substrato geológico e as vegetações de "restinga" (Figura 2), caracterizando-as para cada um dos sete setores morfodinâmicos que englobam as planícies costeiras paulistas (Figura 1).

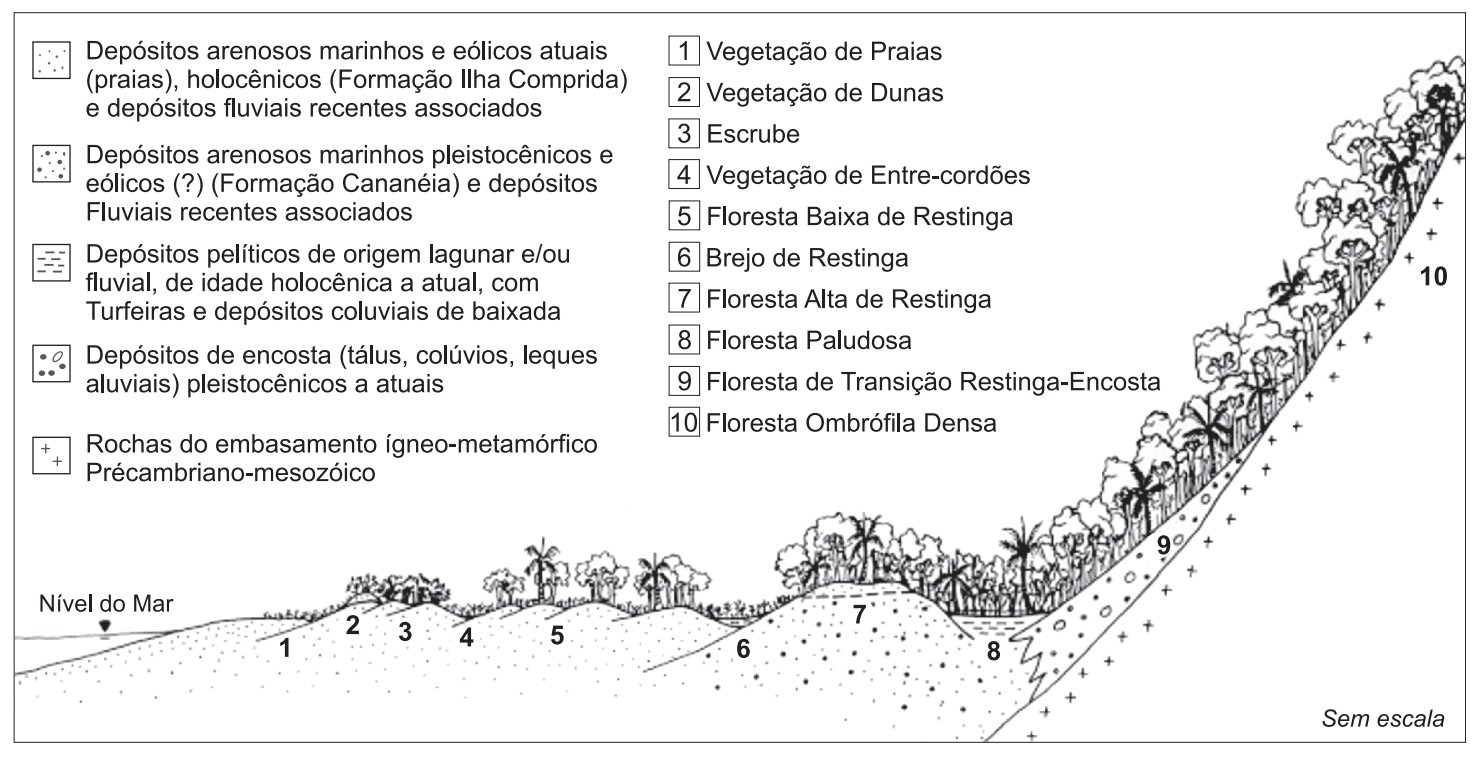

FIGURA 2 - Seção-tipo das unidades geológico-geomorfológicas quaternárias presentes no litoral paulista e sua associação com as fisionomias de "vegetação de restinga" descritas na Resolução Conama n 07/1996 (modificado de SOUZA et al. 1997). 
Assim, de acordo com esses autores, para os setores que compõem o Litoral Norte (V, VI e VII) podem ser observadas várias associações, conforme descrito a seguir.

Setor V (São Sebastião): planícies costeiras de pequeno porte, com presença mais esparsa de restos de terraços marinhos pleistocênicos e sistemas fluviais atuais transversais e paralelos à linha de costa, estes últimos instalados sobre pequenas paleolagunas holocênicas, hoje completamente colmatadas. Ocorrem as fitofisionomias de Vegetação de Praias, Escrube, Floresta Baixa de Restinga, Brejo de Restinga, Floresta Paludosa, Floresta Alta de Restinga e Floresta de Transição Restinga-Encosta. A presença de vegetação de praia é condicionada a áreas sem erosão praial. Brejo e Floresta Paludosa ocorrem em áreas bastante restritas e associadas a paleolagunas.

Setor VI (área associada ao Canal de São Sebastião): planícies costeiras quase inexistentes, predominando sedimentação mista alúvio-coluvial, marinha e coluvial. A "vegetação de restinga" encontra-se quase totalmente degradada, ocorrendo apenas remanescentes de Floresta de Transição Restinga-Encosta.

Setor VII (Caraguatatuba e Ubatuba): pla- nícies costeiras estreitas, com predominância de depósitos marinhos holocênicos atrás dos quais se desenvolveram paleolagunas holocênicas isoladas, ambos cortados por estreitas planícies fluviais. Ocorrem Vegetação de Praias, Escrube, Floresta Baixa de Restinga, Brejo de Restinga, Floresta Paludosa, Floresta Alta de Restinga e Floresta de Transição Restinga-Encosta. A Vegetação de Praias e o Escrube são restritos a poucas áreas (sem erosão); em geral, a Floresta Paludosa ocorre associada a áreas que sofreram intervenções antrópicas, principalmente ao longo da BR-101, em terrenos a montante dessa estrada e mais interiores das planícies costeiras.

Este trabalho apresenta o resultado dos mapeamentos realizados no Litoral Norte de São Paulo, em escala 1:50.000, de Unidades Quaternárias de planície costeira e baixa encosta e da Vegetação Nativa e de seu estado de alteração. Entre os objetivos desses mapeamentos destacam-se: atualização dos mapas do Quaternário costeiro até então disponíveis (SUGUIO \& MARTIN 1978); desenvolvimento de trabalho pioneiro, em São Paulo e no Brasil, de mapeamento das fitofisionomias de "restinga" conforme a legislação ambiental vigente (Resolução Conama nº 07/1996); estabelecimento

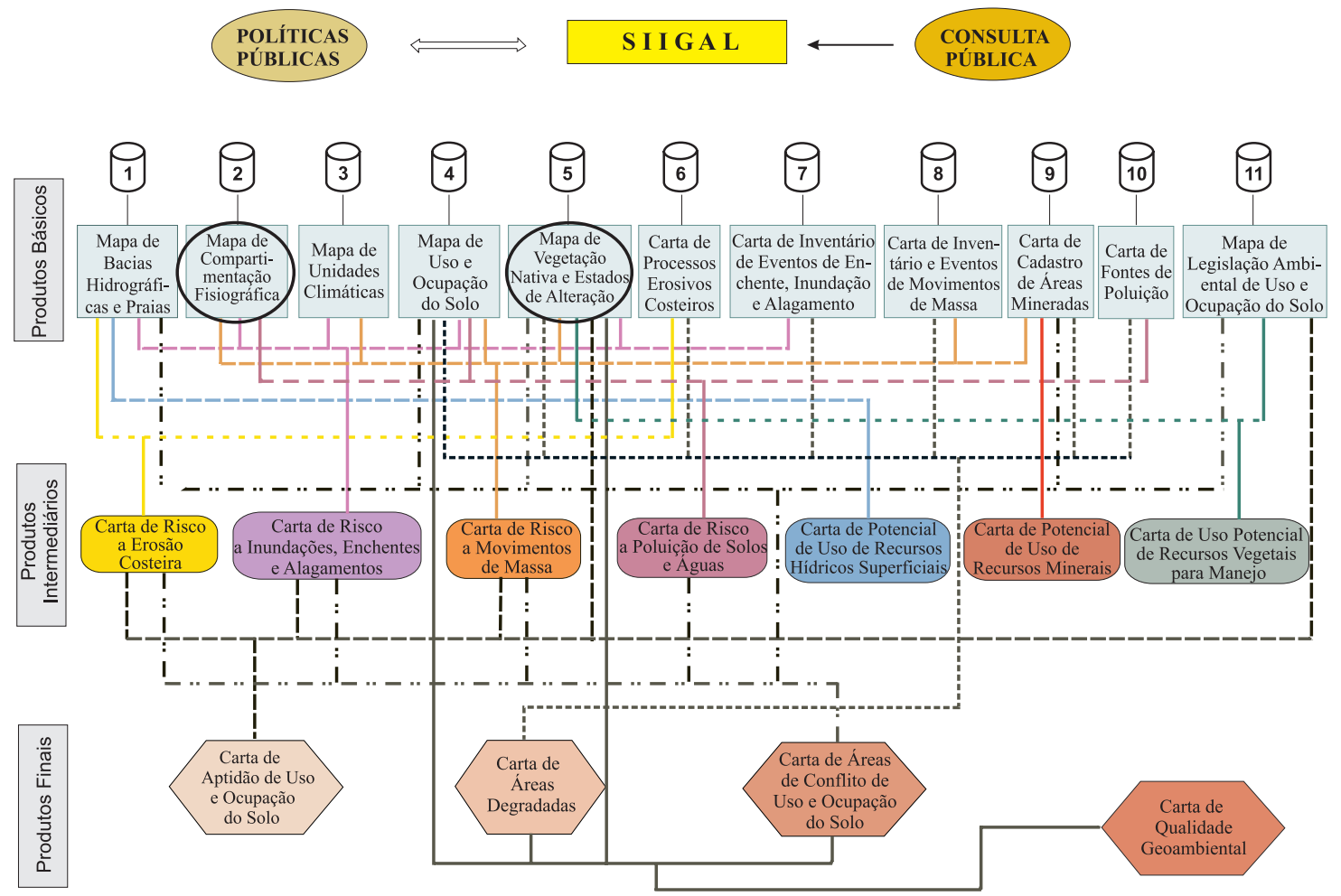

FIGURA 3 - Fluxograma de desenvolvimento do SIIGAL (SOUZA 2005a), com destaque aos mapas apresentados neste trabalho. 
das associações entre essas Unidades Quaternárias e as vegetações costeiras, pois, embora seja de conhecimento da comunidade científica que existe uma estreita relação entre ambas, são raros os trabalhos com esse objetivo; cálculo das porcentagens de supressão das fitofisionomias nativas em relação à paisagem original na área de estudo.

Os mapeamentos foram realizados no âmbito do Projeto SIIGAL - Sistema Integrador de Informações Geoambientais para o Litoral de São Paulo, Aplicado ao Gerenciamento Costeiro (SOUZA 2005a), cuja área-piloto foi o Litoral Norte. O SIIGAL é um sistema especialista e de suporte à tomada de decisões, desenvolvido para auxiliar o Plano Estadual de Gerenciamento Costeiro em seus vários instrumentos. Compreende diagnósti- cos sobre os meios físico, biótico e antrópico da zona costeira, além de diversos tipos de prognósticos ambientais (automatizados no sistema a partir dos bancos de dados vetoriais e alfanuméricos dos diagnósticos), estes últimos sistematizados em cartas de riscos geoambientais, de potencial de uso de recursos naturais, de aptidão de uso, de áreas degradadas e de áreas de conflito de uso, todos integrados automaticamente em uma Carta de Qualidade Geoambiental (Figura 3).

\section{2 ÁREA DE ESTUDO}

O Litoral Norte de São Paulo possui área total de $1.927,88 \mathrm{~km}^{2}$, assim distribuídos: São Sebastião - 402,71 $\mathrm{km}^{2}$; Ilhabela - 337,41
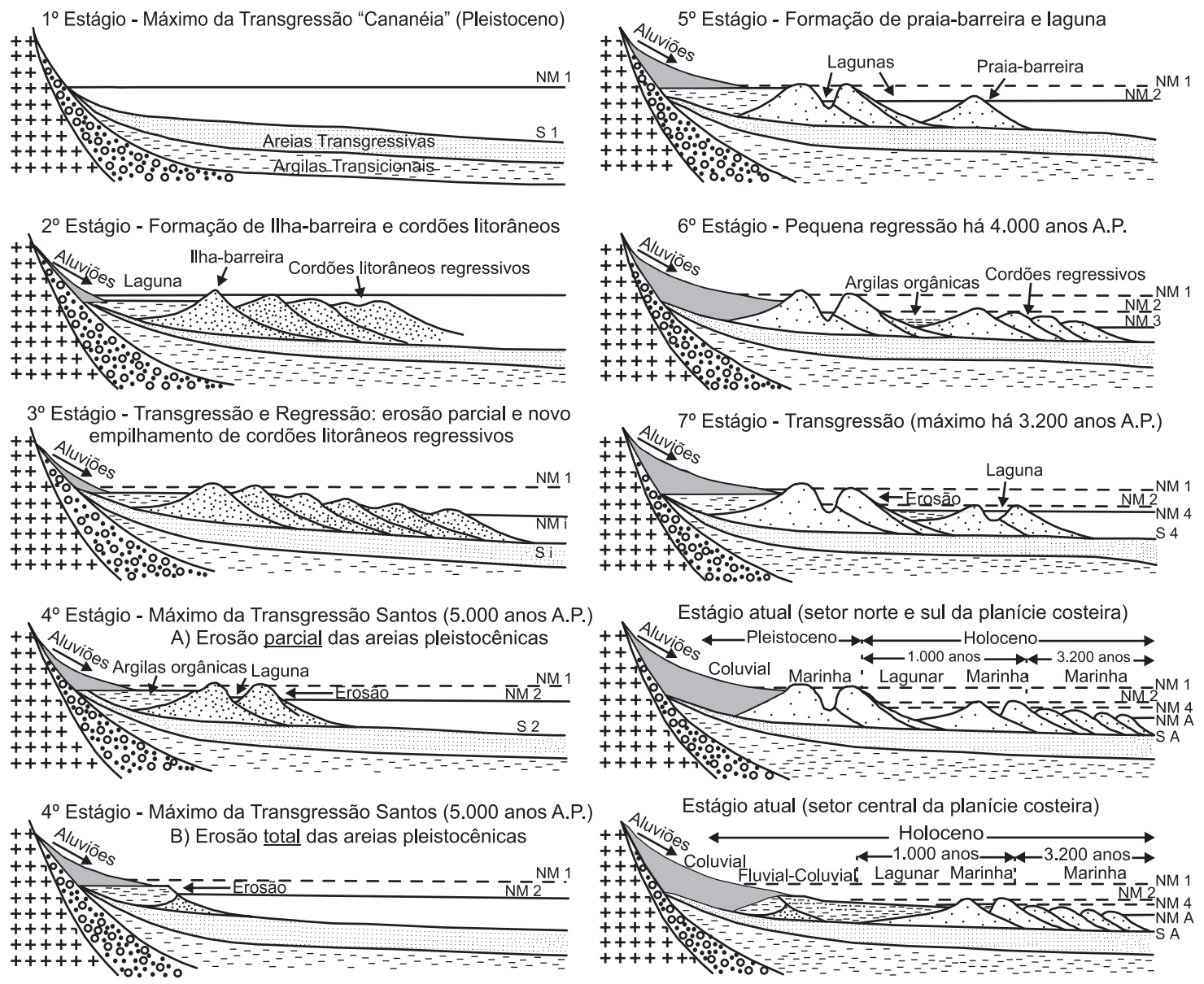

NM 1 - Nível do Mar de 120.000 anos A.P. (Nível "Cananéia") NM i - Nível Intermediário

NM 2 - Nível do Mar de 5.000 anos A.P.

NM 3 - Nivel do Mar de 4.000 anos A.P.

NM 4 - Nível do Mar de 3.200 anos A.P.

S 1 - Superfície de 120.000 anos A.P. (Superfície "Cananeia")

$\mathrm{S}$ i - Superfície Intermediária

S 2 - Superfície de 5.000 anos A.P.

S 4 - Superfície de 3.200 anos A.P.

NM A - Nível Atual

S A - Superfície Atual

FIGURA 4 - Evolução da planície costeira de Caraguatatuba (modificado de SUGUIO \& MARTIN 1976), com base nos trabalhos de SOUZA $(1990,1992)$. 
$\mathrm{km}^{2}$; Caraguatatuba $-479,85 \mathrm{~km}^{2}$; e Ubatuba $-707,91 \mathrm{~km}^{2}$.

A área de estudo compreende os terrenos sedimentares de idade quaternária a atual, presentes nas planícies costeiras e nas baixas encostas da Serra do Mar.

Estudos anteriores envolvendo o mapeamento do substrato sedimentar de algumas dessas planícies costeiras, sua origem e evolução, são encontrados nos trabalhos de SUGUIO \& MARTIN $(1976,1978)$ e SOUZA $(1990,1992)$. A figura 4 mostra a evolução da planície costeira de Caraguatatuba, a qual pode ser estendida para quase todas as planícies costeiras da área de estudo.

$\mathrm{Na}$ mesma época em que o presente estudo se desenvolvia, o Instituto Florestal realizava também o mapeamento da cobertura vegetal nativa do Estado de São Paulo (IF-SMA 2005), em escala 1:50.000. Entretanto, como a legenda utilizada foi a do Projeto RADAM Brasil (caracterização essencialmente do porte arbóreo), não foram individualizadas as diferentes fitofisionomias descritas na Resolução Conama nº 07/1996.

\section{MÉTODOS DE ESTUDO}

Em estudos ambientais, a integração de dados pode ser efetuada através de dois tipos de procedimento, o sintético e o analítico (BOTELHO, 1999).

No procedimento sintético, as informações são conjugadas ao mesmo tempo em que são definidas células cartográficas básicas, ou seja, células ou unidades de planejamento que buscam sintetizar as informações levantadas durante a etapa de diagnóstico ou inventário ambiental, sobre as quais serão efetuados os prognósticos (ex.: aptidão de uso e ocupação do solo, classificações sobre potenciais, riscos ambientais etc.). DENT \& YOUNG (1981) e COOK \& DOORNKAMP (1990) obtiveram essas unidades de planejamento pela identificação de ambientes e sub-ambientes utilizando o método de land-systems, a partir da interpretação de imagens orbitais e fotografias aéreas.

No procedimento analítico são conjugadas informações referentes a cada parâmetro ambiental selecionado, originando um mapa de unidades homogêneas, cujas variações de propriedades são contínuas de lugar para lugar, e se processam a uma distância que varia em função da uniformidade de cada unidade, sendo esta uniformidade dependente da escala de mapeamento (HOLE \& CAMPBELL 1985 apud BOTELHO 1999). Tal procedimento é feito a partir de interpretação de produtos de sensores remotos e levantamentos prévios de campo.

ENGELEN et al. (1995 apud CAPOBIANCO et al. 1999) referiram-se às unidades cartográficas básicas como "células autômatas", as quais facilitam a avaliação dos "objetos ambientais" em modelagens envolvendo análises multivariadas de diversos tipos de atributos. A utilização de células autômatas parece ser a solução conceitual mais adequada para a modelagem e descrição de um fenômeno ambiental, especialmente em procedimentos envolvendo análises multivariadas em Sistemas Geográficos de Informações especialistas e de tomada de decisões (SOUZA 2005a, 2005b). Facilita operações mais complexas de classificações, cruzamentos de dados e permite consultas e visualização de inúmeros atributos integrados (descritores dos meios físico, biótico e antrópico), além de facilitar futuras atualizações do sistema.

XAVIER DA SILVA (2001) denominou essas células de "unidades territoriais de integração de dados", definindo-as como regiões homogêneas caracterizadas por um conjunto específico de características ambientais dominantes, com caráter de integração funcional, mas que admitem uma variabilidade interna em amplitude aceitável.

Todos esses conceitos e paradigmas foram utilizados como base teórica para a elaboração das modelagens ambientais realizadas no SIIGAL (SOUZA 2005a, 2005b).

A base cartográfica digital do SIIGAL foi elaborada a partir de cartas topográficas do IBGE e IGC do ano de 1974, de escala 1:50.000, com atualização da malha viária e parcialmente dos polígonos das praias. Os programas computacionais utilizados foram: MapInfo 7.2 (elaboração do banco de dados vetorial - mapas/cartas), Borland Delphi 7 Professional (linguagem de programação), ESRI MapObjects 2.2 (gerenciador de informações e detentor de funções e ferramentas de programação) e Microsoft SQL Server 2000 (banco de dados alfanuméricos).

3.1 Definição das Unidades Geológico-Geomorfológicas Quaternárias

Uma abordagem metodológica semelhante à de COOK \& DOORNKAMP (1990) e conceitual similar à de XAVIER DA SILVA (2001), ambas baseadas no procedimento sintético, foi readequada à elaboração do Mapa de "Compartimentação Fisiográfica" efetuado no SIIGAL (Figura 3). Nes- 
te mapa, as células cartográficas básicas, denominadas Unidades Básicas de "Compartimentação Fisiográfica” (SOUZA et al. 1998, VEDOVELLO 2000), integram simultaneamente informações geológicas e geomorfológicas, da mesma forma que nos métodos clássicos de mapeamento de depósitos quaternários efetuados a partir de fotografias aéreas verticais (e.g. SOUZA 1990, 2007a). Assim, no caso das planícies costeiras e baixas encostas, esse mapa corresponde, na realidade, ao Mapa de Unidades Geológico-Geomorfológicas Quaternárias (UQ).

A cartografia foi elaborada sobre imagens de satélite Landsat 7 ETM+ (cenas 218_076, 219_076 e 219_077, respectivamente de 25/05/00, 30/04/00 e 03/09/99) georreferenciadas, em fusão colorida 4R5G2B e Pan, e resolução de $15 \mathrm{~m}$, na escala 1: 50.000. Foram utilizados também diversos conjuntos de fotografias aéreas verticais (sobrevôos das décadas de 1970 a 2000), em várias escalas, com o objetivo principal de efetuar refinamentos na delimitação de contatos entre as unidades mapeadas e estabelecer uma melhor caracterização das mesmas. Obviamente, conhecimentos prévios sobre a área de estudo e a evolução das planícies costeiras foram essenciais para a otimização dos trabalhos e eficiência dos resultados.

As UQ foram obtidas a partir da análise sistemática das diferenças de homogeneidade, tropia e assimetria de elementos texturais e tonais, segundo os métodos descritos em SOARES \& FIORI (1976), SOUZA (1990) e VEDOVELLO (2000). Foram consideradas as propriedades espectrais e as características dos alvos, tais como: tipo de elemento textural, densidade de textura, arranjo textural, grau e ordem de estruturação dos elementos. A delimitação das unidades foi feita sobre overlays, com base no princípio da zona homogênea, a qual corresponde a uma área geográfica que guarda determinada associação de diferentes componentes do meio físico.

Como os alvos estudados são depósitos sedimentares de idades quaternária a atual, gerados em diferentes ambientes de sedimentação, a delimitação e caracterização das UQ foi estabelecida com base nos seguintes parâmetros: tipo de sedimento, arranjo e padrão da rede de drenagem, grau de umidade dos terrenos, associações entre os depósitos sedimentares e sua distribuição espacial em relação à linha de costa atual, características da vegetação associada e variações topográficas (neste caso observadas apenas nas fotografias áreas). Obviamente, trabalhos de campo e comparações com estudos anteriores foram necessários e importantes para a finalização da cartografia.

Os overlays produzidos foram transformados em arquivos digitais, posteriormente vetorizados, rasterizados e georreferenciados para a obtenção do mapa digital e dos layouts finais de apresentação.

No banco de dados alfanuméricos do SIIGAL, os "compartimentos fisiográficos" foram descritos em função do domínio geomorfológico, do domínio litológico, da idade dos depósitos e do intervalo do nível médio do lençol freático. As três primeiras características foram utilizadas como referência para estabelecer a nomenclatura de cada unidade, ou seja, seu respectivo identificador no sistema (ID). Assim, por exemplo, na unidade $L P T$ (terraço marinho pleistocênico), $L$ representa o compartimento geomorfológico maior, que se refere à baixada litorânea e baixa encosta, $P$ referese à idade pleistocênica do depósito e $T$ representa sua principal característica geomorfológica e geológica, terraço marinho.

3.2 Mapeamento da Vegetação Nativa e de seus Estados de Alteração

O mapeamento da vegetação também se baseou na identificação de unidades homogêneas e seus arranjos texturais e tonais sobre os produtos de sensoriamento remoto e posterior averiguação de campo. Assim, foram categorizados: cor, tonalidade e teor de umidade, textura, porte, tipos de dossel e de estratos dominantes (presença de emergentes), padrão de drenagem e associação com o substrato (SOUZA et al. 2005).

À exceção dos manguezais, os demais tipos de vegetação foram classificados e caracterizados de acordo com as fitofisionomias descritas na Resolução Conama nº 07/1996 (Figura 2).

Como na escala de trabalho não é possível detalhar o estado exato de preservação, degradação, regeneração ou recuperação da vegetação, optou-se por adotar uma classificação baseada em dois diferentes estados de alteração, a saber:

- vegetação na sua forma primária ou original, ou em estágio avançado ou médio-avançado de regeneração $(P m)$, com alterações mínimas de até $20 \%$ da área, que não afetaram significativamente suas características de estrutura e de espécies;

- vegetação alterada, em estágio inicial a médio de regeneração $(S c)$, após supressão parcial da vegetação ou com alterações por ação antrópica e/ ou causas naturais, com perda significativa de suas 
características de estrutura e espécies, em relação à vegetação primária, com grau de alteração maior do que $20 \%$ da área.

Dada a escala de trabalho e as características fisiográficas do Litoral Norte, os tipos de vegetação associados a praias $(P)$, dunas $(D)$ e entrecordões $(E C)$ e o Escrube $(E s)$ foram agrupados em uma única classe denominada (PESDEC). Isto também foi necessário para permitir que a legenda fosse reaplicável a outros setores costeiros. Note-se bem que muitas vezes algumas dessas vegetações sequer estão presentes, tendo em vista que as dunas são raras no Litoral Norte, as áreas de entrecordões são muito estreitas e a vegetação sobre as praias é dinâmica e não se preserva em praias sob efeito de erosão costeira. Assim, nesse setor costeiro, a $P E S D E C$ é predominantemente representada por estreitas faixas de escrube.

Da mesma forma que para as UQ, também aqui foram elaborados overlays preliminares que, após os trabalhos de campo, foram transformados em arquivos digitais, vetorizados, rasterizados e georreferenciados para a obtenção do mapa digital e dos layouts finais. Nos trabalhos de campo não foram efetuados estudos florísticos ou fitossociológicos da vegetação, mas apenas verificadas a estrutura e as características fisionômicas gerais.

No banco de dados do SIIGAL, cada tipo de vegetação foi caracterizado em função dos seguintes atributos genéricos: associação com o substrato, fisionomia (porte e dossel), tamanho (altura e diâmetro), estratos dominantes, subosque, serapilheira, diversidade de espécies, espécies indicadoras e espécies para manejo. As últimas três características foram baseadas nas descrições contidas na Resolução Conama nº 07/1996.

\section{RESULTADOS E DISCUSSÃO}

\subsection{Unidades Quaternárias}

Foram mapeados seis tipos de UQ de planície costeira e um tipo relacionado à baixa encosta (Figura 5 e Tabela 1).

As UQ são representadas por depósitos marinhos (LHT, LPT), depósitos continentais (LFT, $L M P, L C R)$ e depósitos flúvio-marinhos ( $L O L$, $L C D)$, conforme descrito a seguir.

Planícies de Maré Atuais (LOL): depósitos pelítico-arenosos orgânicos atuais, presentes nas bordas dos canais estuarinos; o nível do lençol freático (NA) é igual ou mais raso que $0,10 \mathrm{~m}$, recebendo influência diária dos ciclos de maré.
Cordões Litorâneos e Terraços Marinhos Holocênicos (LHT): depósitos marinhos arenosos formados por areias finas a médias, muito bem a moderadamente selecionadas, podendo apresentar depósitos eólicos no topo, principalmente nas planícies costeiras maiores. Estão alçados entre 1,50 a 4,0 $\mathrm{m}$ acima do NM atual e amplamente distribuídos em todas as planícies costeiras da área de estudo, com profundidade do NA variando entre 0,40 e 1,10 m. Esses depósitos foram gerados durante o evento Transgressivo-Regressivo Santos, cujo máximo transgressivo ocorreu por volta de 5.100 ${ }^{14} \mathrm{C}$ anos AP (5.600 cal anos AP segundo MARTIN, 2003), atingindo $4 \pm 0,5 \mathrm{~m}$ acima do $\mathrm{NM}$ atual, sendo essas unidades correlatas à Formação Ilha Comprida (SUGUIO \& MARTIN 1976).

Terraços Marinhos Pleistocênicos (LPT): depósitos marinhos arenosos, de idade pleistocênica, formados por areias muito finas a finas, bem a muito bem selecionadas, que se apresentam como terraços bastante erodidos e mais elevados (cotas de 5 a $10 \mathrm{~m}$ acima do NM atual) que os terraços marinhos holocênicos. Correspondem a poucos remanescentes interiorizados nas planícies costeiras de Maresias (São Sebastião), Caraguatatuba e Puruba (Ubatuba), com NA sempre mais profundo que $1,0 \mathrm{~m}$. Foram formados durante o evento Transgressivo-Regressivo Cananéia (120.000 anos A.P.) e, portanto, são correlatos à Formação Cananéia (SUGUIO \& PETRI 1973).

Depósitos Fluviais Holocênicos a Atuais (LFT): depósitos de planície de inundação (areias finas moderadamente selecionadas e pelitos pobremente selecionados), de barras e leito (areias médias a cascalhos muito pobremente selecionados), constituindo ambientes sedimentares ainda em atividade, com $\mathrm{NA} \leq 0,50 \mathrm{~m}$ de profundidade. $\mathrm{Na}$ região, as planícies de inundação são bastante restritas e ocorrem somente em rios de ordem hierárquica igual ou superior a 3 (SOUZA 1998, 2005c).

Depressões Paleolagunares (LCD): depressões formadas por paleolagunas ativas durante $o$ evento Transgressivo Santos, parcialmente preenchidas por sedimentos flúvio-lagunares pelíticos (argilo-siltosos muito pobremente selecionados e ricos em matéria orgânica) que, com a regressão marinha subsequente, foram sendo recobertos por pacotes de até 1,0 $\mathrm{m}$ de espessura de colúvios de baixada (sedimentos areno-síltico argilosos muito pobremente selecionados), de idade holocênica até recente. Estes últimos são provenientes das encostas da Serra do Mar e carreados pelos rios durante as enxurradas, para serem depositados no interior 


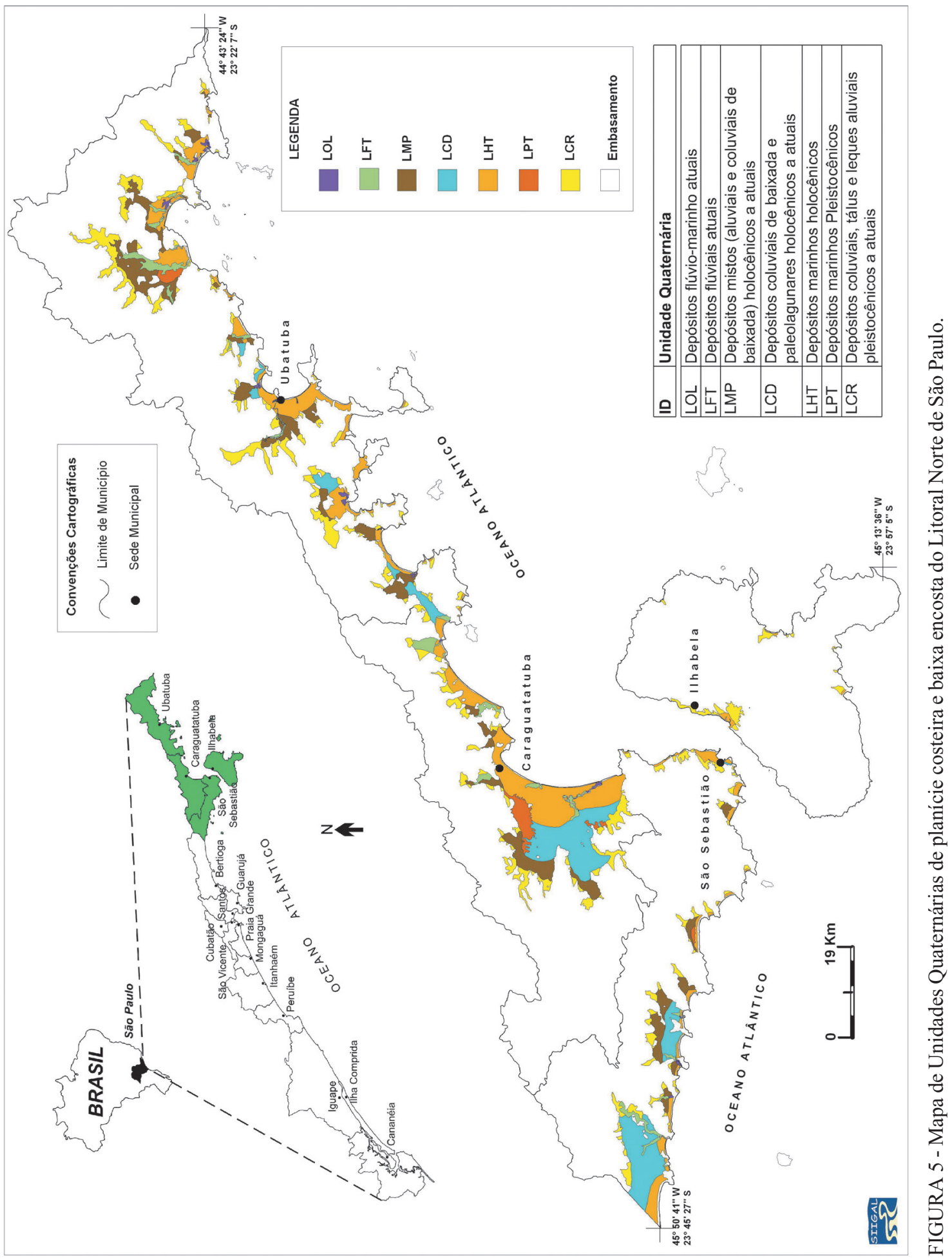


TABELA 1 - Caracterização das unidades quaternárias de planície costeira e baixa encosta no Litoral Norte paulista.

\begin{tabular}{lll}
\hline $\begin{array}{c}\text { Setor } \\
\text { Geomorfológico }\end{array}$ & DQ Dónio Litológico & Domínio Morfológico \\
\hline
\end{tabular}

Depósitos coluviais, tálus e leques aluviais constituídos de sedimentos de matriz areno-

Baixa Encosta LCR síltico-argilosa com grânulos dispersos até matacões, de idade pleistocênica a holocênica; nível médio do lençol freático (NA) $=1,0-2,0 \mathrm{~m}$.
Rampas de baixa declividade

localizadas na baixa encosta

Depósitos lagunares e estuarinos constituídos

$L O L$ de sedimentos pelítico-orgânicos atuais; NA $\leq \quad$ Planícies de maré $0,10 \mathrm{~m}$.

\begin{tabular}{llll} 
LOL & $\begin{array}{l}\text { Depósitos lagunares e estuarinos constituídos } \\
\text { de sedimentos pelítico-orgânicos atuais; NA } \leq \\
0,10 \mathrm{~m} .\end{array}$ & Planícies de maré \\
\hline LFT & $\begin{array}{l}\text { Depósitos fluviais constituídos de sedimentos } \\
\text { arenosos, síltico-arenosos e cascalhos, de idade } \\
\text { holocênica a atual; NA } \leq 0,50 \mathrm{~m} .\end{array}$ & $\begin{array}{l}\text { Planícies de inundação, leito, } \\
\text { barras e terraços fluviais }\end{array}$ \\
\hline Planície & $\begin{array}{l}\text { Depósitos mistos indiferenciados, formados por } \\
\text { depósitos aluviais e coluviais de baixada, de } \\
\text { idade holocênica a atual; NA } \leq 0,50 \mathrm{~m} .\end{array}$ & $\begin{array}{l}\text { Planície sedimentar de muito } \\
\text { baixa declividade localizada ao } \\
\text { fundo das planícies costeiras }\end{array}$ \\
\hline & $\begin{array}{l}\text { Depósitos paleolagunares pelítico-orgânicos } \\
\text { idade holocênica, geralmente reobertos por } \\
\text { colúvios de baixada constituídos de matriz } \\
\text { areno-síltico-argilosa com grânulos de quartzo } \\
\text { dispersos, de idade holocênica a atual; NA } \leq \\
\text { 0,30m. }\end{array}$ & $\begin{array}{l}\text { Depressões paleolagunares } \\
\text { colmatadas e terraços lagunares, } \\
\text { em geral localizadas atrás dos } \\
\text { terraços marinhos holocênicos } \\
\text { ou cortando terraços marinhos } \\
\text { pleistocênicos }\end{array}$ \\
\hline
\end{tabular}

Depósitos marinhos constituídos de areias muito finas a médias, muito bem a moderadamente

LHT selecionadas, de idade holocênica, às vezes recobertas por depósitos eólicos holocênicos a

Cordões litorâneos e terraços atuais; $\mathrm{NA}=0,40-1,10 \mathrm{~m}$.

marinhos

Depósitos marinhos constituídos de areias muito finas a finas bem a muito bem selecionadas,

$L P T$ de idade pleistocênica, às vezes recobertas por

Terraços marinhos depósitos eólicos holocênicos; NA> 1,0m.

TABELA 2 - Distribuição em área das unidades quaternárias de planície costeira e baixa encosta no Litoral Norte paulista (para legenda consultar tabela 1).

\begin{tabular}{ccccccccc}
\hline & \multicolumn{1}{c}{ Depósitos Marinhos } & \multicolumn{2}{c}{$\begin{array}{c}\text { Depósitos Flúvio } \\
\text {-Marinhos }\end{array}$} & \multicolumn{3}{c}{ Depósitos Continentais } \\
\hline Município & $\begin{array}{c}\text { LHT } \\
\left(\mathrm{Km}^{2}\right)\end{array}$ & LPT $\left(\mathrm{Km}^{2}\right)$ & LOL $\left(\mathrm{Km}^{2}\right)$ & $\begin{array}{c}\text { LCD } \\
\left(\mathrm{Km}^{2}\right)\end{array}$ & LFT $\left(\mathrm{Km}^{2}\right)$ & $\begin{array}{c}\text { LMP } \\
\left(\mathrm{Km}^{2}\right)\end{array}$ & LCR $\left(\mathrm{Km}^{2}\right)$ & $\begin{array}{c}\text { Area Total } \\
\left(\mathrm{Km}^{2}\right)\end{array}$ \\
\hline São Sebastião & 20,98 & 0,49 & 0,28 & 27,54 & 3,15 & 11,13 & 13,66 & 77,23 \\
Ilhabela & 1,08 & 0 & 0 & 0 & 0 & 0 & 5,61 & 6,69 \\
Caraguatatuba & 32,73 & 7,08 & 0,30 & 29,27 & 6,45 & 14,51 & 20,74 & 111,08 \\
Ubatuba & 30,44 & 2,14 & 2,07 & 9,22 & 7,69 & 33,42 & 43,46 & 128,44 \\
\hline Área Total $\left(\mathrm{Km}^{2}\right)$ & 85,23 & 9,71 & 2,65 & 66,03 & 17,29 & 59,06 & 83,47 & 323,44 \\
Distribuição $(\%)$ & 26,35 & 3,01 & 0,82 & 20,41 & 5,34 & 18,26 & 25,81 & 100,00 \\
\hline
\end{tabular}


dessas depressões. Estão localizadas no meio e ao fundo das planícies costeiras e apresentam NA igual ou mais raso que $0,30 \mathrm{~m}$.

Depósitos Mistos (LMP): constituem uma associação indiferenciada de depósitos aluviais e colúvios de baixada (semelhantes aos descritos anteriormente), holocênicos a atuais, recobrindo as porções mais distais e planas da planície costeira, junto às encostas da Serra do Mar. O NA está frequentemente em profundidade $\leq 0,50 \mathrm{~m}$.

Depósitos de Encosta (LCR): englobam os depósitos de baixa a média encosta como rampas de colúvio, tálus e leques aluviais de idade pleistocênica a atual. São constituídos de sedimentos com ampla variação granulométrica, desde argilas até matacões, apresentando NA entre 1,0 e 2,0 m de profundidade.

A área total ocupada por esses ambientes sedimentares quaternários é de $323,44 \mathrm{~km}^{2}$ (Tabela 2).

A distribuição em área de cada UQ reflete bem a fisiografia costeira e a evolução geológica quaternária da região. Nas pequenas planícies costeiras predominam depósitos marinhos holocênicos (26,35\%), depósitos flúvio-lagunares e continentais que colmataram paleolagunas holocênicas rasas (20,41\%) e depósitos alúvio-coluviais (18,26\%). Afloramentos de depósitos marinhos pleistocênicos são raros $(3,01 \%)$ e resistiram à erosão do mar transgressivo holocênico apenas nas planícies maiores, como em Caraguatatuba, Maresias (São Sebastião) e Puruba (Ubatuba). Como a Serra do Mar está sempre presente, os depósitos de encosta estão amplamente distribuídos pela região, totalizando $25,81 \%$ da área. À exceção do Rio Juqueriquerê (Caraguatatuba), as demais bacias de drenagem são também pequenas, portanto, seus rios desenvolvem planícies de inundação $(5,34 \%)$ restritas e planícies de maré de pequena extensão $\left(0,82 \mathrm{~km}^{2}\right)$ nas bordas dos canais estuarinos.

\subsection{Vegetação Nativa e Estados de Alteração}

Foram mapeados oito tipos de fitofisionomias (Figura 6), em estágios desde pouco até muito alterados: Vegetação sobre Praias e Escrube (PEsDEC), Manguezal (Mg), Floresta Baixa de Restinga $(F b R)$, Floresta Alta de Restinga $(F a R)$, Floresta Alta de Restinga Úmida $(F a R u)$, Floresta Paludosa ( $\mathrm{Pa}$ ), Brejo de Restinga ( $\mathrm{Br}$ ) e Floresta de Transição Restinga-Encosta (Tr) (Tabela 3).

A Floresta Alta de Restinga Úmida $(F a R u)$ é uma fitofisionomia nova, não descrita na Resolução Conama n ${ }^{\circ}$ 07/1996. Foi preliminarmente denominada assim, pois caracteriza-se pela mistura entre a Floresta Alta de Restinga e a Floresta Paludosa, possuindo características fisionômicas e florísticas de ambas (LOPES 2007) e lençol freático subaflorante. A FaRu também foi mapeada em

TABELA 3 - Tipos de vegetação nativa e estágios de alteração presentes na planície costeira e baixa encosta do Litoral Norte de São Paulo e sua respectiva distribuição em área (para legenda consultar figura 6).

\begin{tabular}{|c|c|c|c|c|c|c|}
\hline VEGETAÇ $\tilde{A} O$ & $\begin{array}{c}\text { São Sebastião } \\
\left(\mathrm{Km}^{2}\right)\end{array}$ & $\begin{array}{c}\text { Ilhabela } \\
\left(\mathrm{Km}^{2}\right)\end{array}$ & $\begin{array}{c}\text { Caraguatatuba } \\
\left(\mathrm{Km}^{2}\right)\end{array}$ & $\begin{array}{c}\text { Ubatuba } \\
\left(\mathrm{Km}^{2}\right)\end{array}$ & $\begin{array}{c}\text { Área Total } \\
\left(\mathrm{Km}^{2}\right)\end{array}$ & $\begin{array}{c}\text { Distribuição } \\
(\%)\end{array}$ \\
\hline $\mathrm{PmTr}$ & 18,82 & 16,96 & 10,67 & 42,02 & 88,47 & 31,70 \\
\hline ScTr & 14,97 & 4,71 & 24,13 & 49,49 & 93,30 & 33,43 \\
\hline PmFaR & 0 & 0 & 0 & 3,87 & 3,87 & 1,39 \\
\hline ScFaR & 3,67 & 0 & 8,61 & 15,37 & 27,65 & 9,91 \\
\hline PmFaRu & 22,74 & 0 & 2,26 & 2,02 & 27,02 & 9,67 \\
\hline ScFaRu & 3,08 & 0 & 7,56 & 2,31 & 12,95 & 4,64 \\
\hline PmFbR & 0 & 0 & 0 & 0,10 & 0,10 & 0,03 \\
\hline$S c F b R$ & 0,47 & 0,24 & 1,60 & 0,93 & 3,24 & 1,88 \\
\hline$P m P a$ & 0 & 0 & 0 & 0 & 0 & 0 \\
\hline $\mathrm{ScPa}$ & 0 & 0 & 0 & 2,77 & 2,77 & 0,99 \\
\hline $\mathrm{PmBr}$ & 2,36 & 0 & 1,34 & 0 & 3,70 & 1,32 \\
\hline$S c B r$ & 0,59 & 0 & 2,57 & 8,05 & 11,21 & 4,02 \\
\hline$P m M g$ & 0 & 0 & 0 & 0,80 & 0,80 & 0,29 \\
\hline$S c M g$ & 0,27 & 0 & 0,30 & 1,21 & 1,78 & 0,64 \\
\hline$P, E s$ & 0 & 0 & 0 & 0,26 & 0,26 & 0,09 \\
\hline Total & 66,97 & 21,91 & 59,04 & 129,20 & 277,12 & 100,00 \\
\hline
\end{tabular}




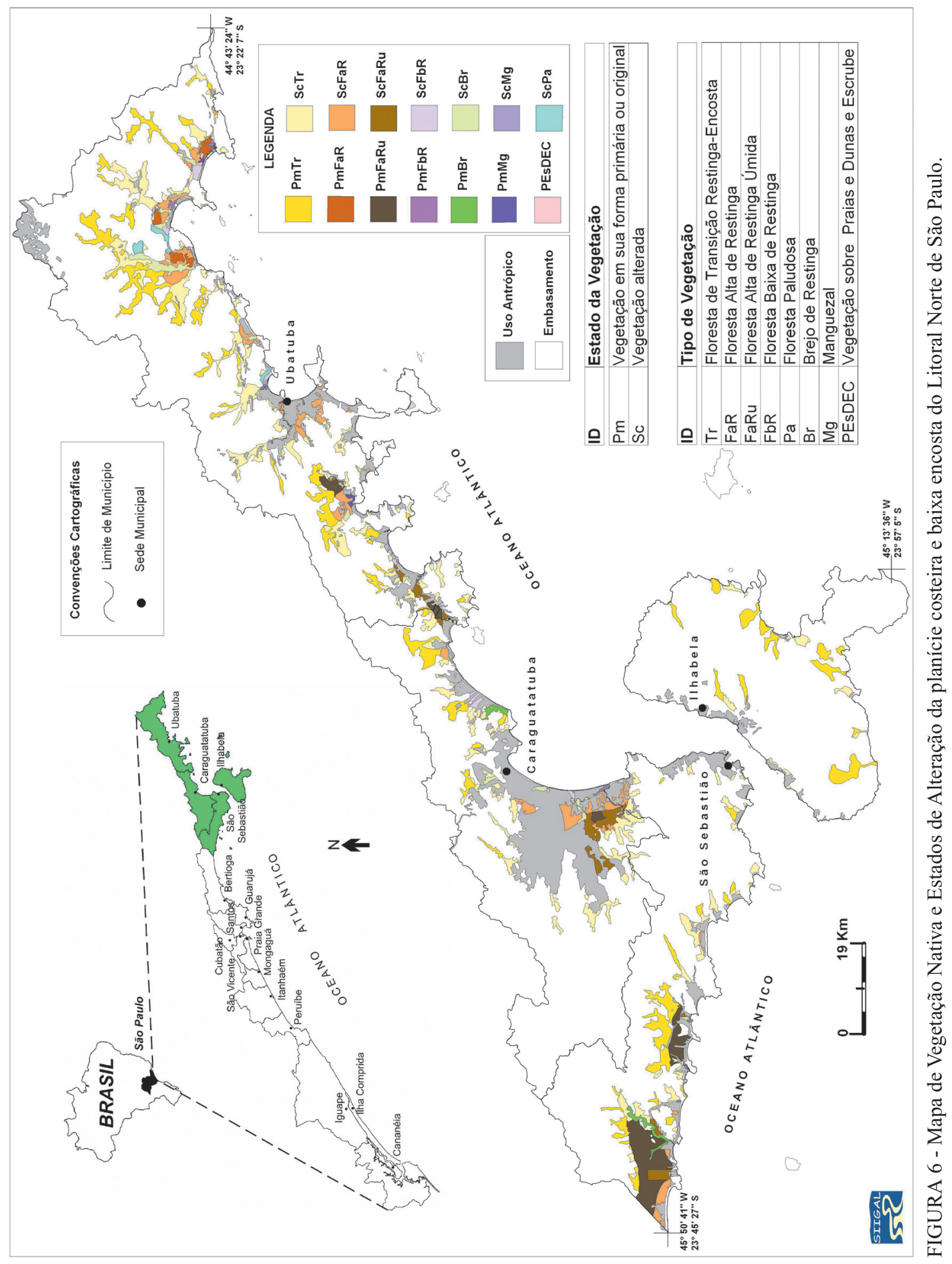


Bertioga, município da Baixada Santista contíguo a São Sebastião (SOUZA et al. 2007, 2008, 2009, LOPES 2007).

As vegetações mapeadas ocorrem predominantemente em suas formas alteradas $(55,51 \%)$, à exceção da FaRu (Tabela 3).

A fitofisionomia mais expressiva é $T r$, totalizando $65,13 \%$ da área de estudo (estados preservados e alterados), dos quais quase a metade encontra-se em Ubatuba $\left(91,51 \mathrm{~km}^{2}\right.$ do total de 181,77 $\mathrm{km}^{2}$ ). ScFar e PmFaRu ocorrem em pouco mais de $27 \%$ da área cada uma, seguidas de ScFaRu $(12,95 \%)$ e $\operatorname{ScBr}(11,21 \%)$.

Os únicos remanescentes melhor preservados (Pm) de FaR, FbR, Mg e PEsDEC ocorrem em Ubatuba, distribuídos respectivamente em: 3,87 $\mathrm{km}^{2}(1,39 \%), 0,1 \mathrm{~km}^{2}(0,03 \%), 0,8 \mathrm{~km}^{2}(0,29 \%)$ e $0,26 \mathrm{~km}^{2}(0,09 \%)$.

Fisionomias do tipo $\mathrm{PmPa}$ não foram encontradas nessa escala de mapeamento. Apesar desse tipo de vegetação ser considerado de clímax e, portanto, não possuir estágios sucessionais, formas secundárias de $\mathrm{Pa}(\mathrm{ScPa})$ foram identificadas principalmente em Ubatuba e São Sebastião, ao longo da Rodovia BR-101. Estas resultam de intervenções antrópicas na rede de drenagem a montante do eixo da estrada, que causaram o afogamento de terrenos de substrato pelítico (depressões paleolagunares rasas). De maneira similar, algumas formas de Brejos de Restinga, que também são de clímax, foram mapeadas como $\mathrm{ScBr}$ por serem resultantes de intervenções antrópicas localizadas.

4.3 Associações entre as Unidades Quaternárias e a Vegetação Nativa

Quando se superpõem os mapas de Unidades Quaternárias e de Vegetação Nativa, encontra-se uma forte associação entre os polígonos. As tabelas $4 \mathrm{a}$ e $4 \mathrm{~b}$ representam duas maneiras diferentes e complementares de mostrar como se dão essas associações.

De maneira geral, são encontradas as seguintes associações:

a) Vegetação de Praia, em praias arenosas que não sofrem erosão;

b) Manguezal, em planícies de maré, na porção estuarina dos rios maiores (a partir da $3^{\circ}$ ordem hierárquica);

c) Escrube na porção dos cordões litorâneos holocênicos mais próxima à praia;

d) Florestas Baixa e Alta de Restinga, so- mente nos substratos de origem marinha, holocênicos e pleistocênicos, embora nestes últimos ocorra somente Floresta Alta de Restinga;

e) Brejo de Restinga, apenas na planície de inundação dos rios;

f) Floresta Alta de Restinga Úmida, associada às depressões paleolagunares rasas e, localmen-

TABELA 4 - (a) Associações entre as Fitofisinomias remanescentes e as Unidades Quaternárias na planície costeira e baixa encosta do Litoral Norte de São Paulo (para legenda consultar tabelas 1 e 3 ).

\begin{tabular}{cl}
\hline VEGETAÇÃO & \multicolumn{1}{c}{ UNIDADES QUATERNÁRIAS } \\
\hline$T r$ & LCR e LMP \\
\hline$F a R u$ & $\begin{array}{l}\text { LCD (paleolagunas rasas) e } \\
\text { localmente } L M P \text { muito úmidos }\end{array}$ \\
\hline$F a R$ & $\begin{array}{l}\text { LPT e } L H T \text { (terraços marinhos mais } \\
\text { antigos) }\end{array}$ \\
\hline$F b R$ & $\begin{array}{l}\text { LHT (cordões litorâneos e terraços } \\
\text { marinhos) }\end{array}$ \\
\hline$P a$ & $\begin{array}{l}\text { LCD (paleolagunas mais profundas) } \\
\text { e localmente } L M P \text { muito úmidos }\end{array}$ \\
\hline$B r$ & LFT (planície de inundação) \\
\hline$M g$ & LOL \\
\hline$E s$ & $\begin{array}{l}\text { LHT (cordões litorâneos mais } \\
\text { jovens, podendo estar recobertos } \\
\text { por depósitos eólicos holocênicos } \\
\text { a atuais) }\end{array}$ \\
\hline$P$ & \begin{tabular}{l}
$P r$ (praias arenosas) \\
\hline
\end{tabular}
\end{tabular}

TABELA 4 - (b) Associações entre as Unidades Quaternárias (UQ) e a Vegetação nativa remanescente na planície costeira e baixa encosta do Litoral Norte de São Paulo (para legenda consultar tabelas 1 e 3).

\begin{tabular}{|c|c|c|}
\hline & UQ & VEGETAÇÃO \\
\hline \multirow{3}{*}{$\begin{array}{l}\text { Depósitos } \\
\text { Marinhos }\end{array}$} & $\operatorname{Pr}$ & $P$ \\
\hline & $L H T$ & $E s, F b R, F a R$ \\
\hline & $L P T$ & $F a R$ \\
\hline \multirow{2}{*}{$\begin{array}{c}\text { Depósitos } \\
\text { Flúvio-Marinhos }\end{array}$} & $L O L$ & $M g$ \\
\hline & $L C D$ & $F a R u, P a$ \\
\hline \multirow{4}{*}{$\begin{array}{c}\text { Depósitos } \\
\text { Continentais }\end{array}$} & $L F T$ & $B r$ \\
\hline & $L M P$ & $T r, F a R u$, \\
\hline & & Pa antrópica \\
\hline & $L C R$ & $\operatorname{Tr}$ \\
\hline
\end{tabular}


TABELA 5 - Distribuição em área de Unidades Quaternárias (UQ), Vegetação nativa - VEG (excluída a Floresta de Transição Restinga-Encosta no embasamento - Tr/Embas) e áreas desmatadas, bem como as porcentagens de supressão da vegetação original no Litoral Norte paulista.

\begin{tabular}{|c|c|c|c|c|c|}
\hline & $\begin{array}{c}\text { São } \\
\text { Sebastião }\end{array}$ & Ilhabela & Caraguatatuba & Ubatuba & Total \\
\hline UNIDADES QUATERNÁRIAS $\left(\mathrm{Km}^{2}\right)$ & 77,23 & 6,69 & 111,08 & 128,44 & 323,44 \\
\hline VEGETAÇÃO REMANESCENTE $\left(\mathrm{Km}^{2}\right)$ & 66,97 & 21,91 & 59,04 & 129,20 & 277,12 \\
\hline $\mathrm{Tr} /$ Embasamento $\left(\mathrm{Km}^{2}\right)$ & 17,09 & 19,97 & 19,69 & 37,30 & 94,05 \\
\hline$(V E G)-(\operatorname{Tr} / E m b a s)\left(K^{2}\right)$ & 49,88 & 1,94 & 39,35 & 91,90 & 183,07 \\
\hline ÁREA TOTAL DESMATADA $\left(\mathrm{Km}^{2}\right)$ & 27,35 & 4,75 & 71,73 & 36,54 & 140,37 \\
\hline $\begin{array}{c}\text { PORCENTAGEM DE SUPRESSÃO DA } \\
\text { VEGETAÇÃO ORIGINAL }\end{array}$ & 35,41 & 71,00 & 64,58 & 28,45 & 43,40 \\
\hline
\end{tabular}

te, sobre os depósitos mistos quando estes bordejam as depressões paleolagunares;

g) Floresta Paludosa, na porção mais profunda dessas depressões, embora possam ocorrer também sobre depósitos mistos pelíticos, quando estes sofreram afogamento da rede de drenagem por intervenções antrópicas;

h) Floresta de Transição Restinga-Encosta, sempre associada aos materiais coluvionares, tanto nas encostas como na planície costeira (depósitos mistos).

É interessante constatar que, às vezes, a ocorrência de Floresta de Transição RestingaEncosta estende-se até cotas mais elevadas que $100 \mathrm{~m}$, adentrando terrenos da média encosta, na parte superior das rampas de colúvio, no contato com o embasamento ígneo-metamórfico, onde os solos são mais espessos (Tabelas 2 e 3). Por esse motivo, a somatória de PmTr e $\operatorname{ScTr}\left(181,77 \mathrm{~km}^{2}\right)$ excedeu a somatória de $L C R$ e $\operatorname{LMP}\left(142,53 \mathrm{~km}^{2}\right)$.

Comparando as áreas de abrangência espacial das UQ e das vegetações associadas nos quatro municípios estudados (Tabelas 2, 3), observase que, de maneira geral, não há correspondência entre ambas. As diferenças são devidas ao desmatamento (principalmente para urbanização) e também ao fato comentado acima.
A situação de alguns ecossistemas é preocupante, como os formados pela Floresta Baixa de Restinga, que praticamente desapareceu desse litoral. Restam pequenos remanescentes em estado de melhor preservação apenas em Ubatuba $\left(0,10 \mathrm{~km}^{2}\right)$, em locais pouco ocupados e no interior do Núcleo Picinguaba do Parque Estadual da Serra do Mar. Nos demais municípios essa fitofisionomia ocorre apenas no estado alterado, totalizando, juntamente com Ubatuba, $3,24 \mathrm{~km}^{2}$. Isto se deve ao fato de que essa vegetação ocorre principalmente sobre os depósitos marinhos holocênicos localizados próximos à linha de costa, que são os terrenos mais nobres e, portanto, os primeiros a serem ocupados. Entretanto, não se pode descartar a hipótese de que essa vegetação seja um estágio sucessional da Floresta Alta de Restinga, hipótese esta que merece ser mais bem explorada (SOUZA et al. 2009).

A Floresta Alta de Restinga, em seu melhor estado de conservação, também ocorre somente em Ubatuba, recobrindo área total de $3,87 \mathrm{~km}^{2}$. Os remanescentes alterados totalizam $27,65 \mathrm{~km}^{2}$ nos quatro municípios.

Assim, supondo que as florestas alta e baixa de Restinga ocupassem originalmente uma área total de $94,94 \mathrm{~km}^{2}$ (somatória de LHT e LPT), então, como hoje restam apenas $34,86 \mathrm{~km}^{2}$ de seus remanescentes, preservados e alterados, conclui-se 
que no Litoral Norte já foram devastados 63,28\% dessas fitofisionomias.

O Escrube também é uma fitofisionomia ameaçada, seja pela mesma razão apontada acima, ou pela erosão acelerada em algumas praias (SOUZA, 2007b).

Da área total originalmente recoberta por Brejos de Restinga, que deveriam ocupar no mínimo $17,29 \mathrm{~km}^{2}(L F T)$, restam $14,91 \mathrm{~km}^{2}$, o que corresponde a uma porcentagem de supressão da ordem de $13,77 \%$.

Já para os Manguezais, a conservação tem sido muito eficaz, pois apenas $2,64 \%$ foram suprimidos.

Para as demais fitofisionomias, não é possível calcular a taxa de alteração da vegetação individualmente, pois recobrem mais de um tipo de substrato.

Para o cálculo das porcentagens totais de supressão da vegetação original em cada município e na região, procedeu-se previamente à eliminação das áreas de Floresta de Transição Restinga-Encosta na média encosta (altas rampas de colúvio, formada por embasamento com solos espessos), para então obter o balanço da supressão da vegetação remanescente nas planícies costeiras e baixas encostas e o percentual de supressão da vegetação original correspondente (Tabela 5).

As porcentagens de supressão da vegetação original calculadas para a região são preocupantes. Em média, quase $50 \%$ das fitofisionomias nativas originalmente existentes nessas planícies costeiras e baixas encostas já foram suprimidas. Ilhabela apresenta os maiores índices, com $71 \%$ de supressão da vegetação original, sendo que somente para as suas diminutas planícies costeiras essa taxa é de quase $100 \%$ (restam apenas $0,24 \mathrm{~km}^{2}$ ). Caraguatatuba apresenta porcentagem de supressão da vegetação original de $64,6 \%$, e ainda guarda importantes remanescentes até na planície costeira de Caraguatatuba. Estes, entretanto, estão bastante ameaçados pelo avanço da urbanização esperado para as próximas décadas, em conseqüência da ampliação do Porto de São Sebastião e dos projetos da Petrobrás. São Sebastião, cuja porcentagem de supressão da vegetação original é da ordem de $35,4 \%$, ainda conserva extensas áreas de planícies costeiras pouco ocupadas, como Boracéia (Reserva Indígena), Una e Baleia, principalmente porque essas áreas apresentam problemas geotécnicos que impedem uma fácil ocupação (depressões paleolagunares mais amplas). A menor porcentagem de supressão da vegetação original ocor- re em Ubatuba, com apenas $28,5 \%$. Isto se deve, principalmente, à grande distância da capital do Estado e ao fato de que o acesso ao município foi facilitado somente após a construção da BR-101, há pouco mais de 30 anos. Além disso, são importantes também o formato longilíneo do município e a ocupação mais concentrada ao redor do núcleo urbano e de sua porção sul.

\section{CONCLUSÕES}

Os resultados obtidos são compatíveis com as características fisiográficas regionais, com planícies costeiras pequenas e bordejadas pelas encostas íngremes da Serra do Mar. Neste contexto, nas planícies costeiras predominam depósitos continentais (coluviais e aluviais), ora recobrindo o fundo das planícies costeiras, ora preenchendo as depressões paleolagunares existentes nas planícies maiores, seguidos de depósitos marinhos holocênicos. Os depósitos marinhos pleistocênicos são representados por pequenos remanescentes nas planícies mais largas, nas quais também os depósitos continentais de planície costeira apresentam maior expressão. Os rios são, em geral, de pequeno porte (predominam bacias de ordens hierárquicas 3 e 4) e, portanto, desenvolvem planícies de inundação restritas, bem como pequenos estuários em suas desembocaduras, onde se localizam estreitas planícies de maré.

Dentre as oito fisionomias de vegetação descritas na Resolução Conama $n^{\circ}$ 07/1996, sete ocorrem na área de estudo, a saber: Vegetação sobre Praias, Escrube, Floresta Baixa de Restinga, Floresta Alta de Restinga, Floresta Paludosa, Brejo de Restinga e Floresta de Transição RestingaEncosta. Além destas, um novo tipo de fitofisionomia foi encontrado, preliminarmente denominado Floresta Alta de Restinga Úmida. Essa vegetação ocorre sobre substratos pelítico-psamíticos que preenchem paleolagunas holocênicas rasas colmatadas por depósitos continentais, hoje cortadas por complexa malha de canais de drenagem e apresentando lençol freático muito raso. Manguezais de pequena extensão completam as dez fitofisionomias mapeadas na região.

A maioria dessas fitofisionomias encontrase predominantemente em seu estado alterado, exceto a Floresta Alta de Restinga Úmida e a Floresta de Transição Restinga-Encosta, cujos estados preservado e alterado apresentam distribuição em área quase equivalente. Isso pode ser explicado pelas condições geotécnicas desfavorá- 
veis à ocupação nesses tipos de terreno e, também, pela sua localização ao fundo das planícies costeiras e sopé da Serra do Mar.

As associações encontradas entre essas vegetações e os ambientes sedimentares quaternários são marcantes, destacando-se: (a) ambientes marinhos-praiais holocênicos e pleistocênicos e Florestas Alta e Baixa de Restinga, além de estreitas faixas de Escrube localizadas nas porções mais próximas às praias (sedimentos holocênicos mais jovens); (b) ambientes paleolagunares e Florestas Alta de Restinga Úmida e Paludosa; (c) ambientes continentais ao fundo das planícies costeiras até a baixa encosta e Floresta de Transição RestingaEncosta; (d) ambientes fluviais de planície de inundação e Brejo de Restinga; (e) ambientes estuarinos de planície de maré e Manguezais; (f) ambientes praiais atuais e Vegetação de Praia.

As porcentagens de supressão da vegetação original calculadas para a região são preocupantes. Em média, quase $50 \%$ das fitofisionomias nativas originalmente existentes nessas planícies costeiras e baixas encostas já foram suprimidas, variando entre $71 \%$ em Ilhabela, 64,6\% em Caraguatatuba, 35,4\% em São Sebastião e $28,5 \%$ em Ubatuba. Além disso, o desaparecimento de alguns ecossistemas parece inevitável, a exemplo dos formados por Escrube e Floresta Baixa de Restinga sobre cordões litorâneos holocênicos, ambos restritos aos terrenos frontais às praias e, portanto, as áreas mais nobres para a ocupação antrópica.

Os resultados aqui apresentados corroboram, em geral, as associações mostradas na figura 1 e demonstram haver fortes relações entre a "vegetação de restinga" e o substrato sedimentar, relações estas raramente comprovadas na literatura. Assim, contribuem para um melhor conhecimento dos ecossistemas de planície costeira, sendo úteis à elaboração de projetos de recuperação de áreas degradadas, bem como para revisões futuras da legislação vigente e ações de gerenciamento costeiro.

\section{AGRADECIMENTOS}

Agradecimentos são devidos à FAPESP, pelo apoio financeiro ao Projeto SIIGAL (Processo $n^{\circ}$ 1998/14.277-2). Também à Pesquisadora Científica Elisabete A. Lopes, do Instituto de Botânica-SMA e à Geógrafa Ana F. Xavier, da Fundação Florestal, pelas contribuições em parte dos trabalhos de sensoriamento remoto para a caracterização da vegetação.

\section{REFERÊNCIAS BIBLIOGRÁFICAS}

BENDAZOLI, A.; D'ERCOLE, R.; LAM, M.; SUGIYAMA, M.; LOPES, E.A.; KIRIZAWA, M. et al. 1996. Descrição da dinâmica sucessional de vegetação de restinga no Estado de São Paulo. In: INTERNATIONAL SYMPOSIUM ON FOREST ECOSYSTEMS, 4, Belo Horizonte, Resumos, 298-209.

BOTELHO, R.G.M. 1999. Planejamento Ambiental em Microbacia Hidrográfica. In: A.J.T. Guerra et al. (org.). Erosão e Conservação dos Solos. Conceitos, Temas e Aplicações. Bertrand Brasil, Rio de Janeiro, p. 269-300.

CAPOBIANCO, M.; DE VIENDRE, H.J.; NICHOLLS, R.J. \& STIVE, M.J.F. 1999. Coastal area impact and vulnerability assessment: the point of view of a morphodynamic modeler. Journal of Coastal Research, 15(3): 701-716.

COOK, R.U. \& DOORNKAMP, J.C. 1990. Geomorphology in Environmental Management: a New Introduction. $2^{\text {nd }}$ Edition. Oxford University Press, New York, 410p.

DENT, D. \& YOUNG, A. 1981. The Land Systems Approach. In: G. Allen \& A. Unwin. Soil Survey and Land Evaluation, London, p. 104-114.

FILET, M.; SOUZA, C.R de G.; XAVIER, A.F.; BÜSCHEL, E.C.G.; MORAES, M.B.R. \& POLETI, A.E. 2001. Gerenciamento costeiro e os estudos do Quaternário no Estado de São Paulo, Brasil. Revista Pesquisas em Geociências, 28(2): 475-486.

IF-SMA. INSTITUTO FLORESTAL - SECRETARIA DO MEIO AMBIENTE DO ESTADO DE SÃO PAULO. 2005. Inventário Florestal da Vegetação Natural do Estado de São Paulo. Escala 1:50.000. São Paulo, SMA-SP/IF, 200p.

LOPES, E.A. 2007. Formações florestais de planície costeira e baixa encosta e sua relação com o substrato geológico nas bacias dos rios Itaguaré e Guaratuba (Bertioga - SP). Instituto de Botânica, São Paulo, Dissertação de Mestrado, 81 p. + anexos. 
MARTIN, L. 2003. Holocene sea-level history along eastern-southeastern Brazil. Anuário do Instituto de Geociencias-UFRJ, 26: 13-24.

RIZZINI, C.T. 1963. Nota prévia sobre a divisão fitogeográfica do Brasil. Revista Brasileira de Geografia, 25(1): 3-64.

\section{SEADE - FUNDAÇÃO SISTEMA ESTADUAL} DE ANÁLISE DE DADOS. 2008. População. Perfil Municipal e Projeções Populacionais. (www.seade.sp.gov.br Acesso em 05/11/2008).

SMA - SECRETARIA DO MEIO AMBIENTE DO ESTADO DE SÃO PAULO DO ESTADO DE SÃO PAULO. 1998. Mata Atlântica: Um Projeto de Conservação. SMA, Governo do Estado de São Paulo, 71p.

SOARES, P.C. \& FIORI, A.P. 1976. Lógica e sistemática na análise e interpretação de fotografias aéreas em Geologia. Notícia Geomorfológica, 16(32):71-104.

SOSMA/INPE - FUNDAÇÃO SOS MATA ATLÂNTICA / INSTITUTO NACIONAL DE PESQUISAS ESPACIAIS. 2008. Atlas dos Remanescentes Florestais da Mata Atlântica: Período 2000-2005. (<http://mapas.sosma.org.br $>$ Acesso em 05/11/2008).

SOUZA C.R. de G. 1990. Considerações sobre os Processos Sedimentares Quaternários e Atuais na Região de Caraguatatuba, Litoral Norte do Estado de São Paulo. Instituto Oceanográfico, Universidade de São Paulo, São Paulo, Dissertação de Mestrado, 314p.

SOUZA C.R. de G. 1992. Considerações sobre a origem de um depósito marinho pleistocênico no litoral norte do Estado de São Paulo. Boletim do IG-USP, Série Científica, 23: 43-54.

SOUZA, C.R. de G. 1997. As Células de Deriva Litorânea e a Erosão nas Praias do Estado de São Paulo. São Paulo. Instituto de Geociências, Universidade de São Paulo, São Paulo, Tese de Doutoramento, 2 volumes.

SOUZA, C.R. de G. 1998. Flooding in the São Sebastião region, northern coast of São Paulo state, Brazil. Anais da Academia Brasileira Ciências, 70(2): 353-366.
SOUZA, C.R. de G. 2003/2004. Projeto SIIGAL: O SIGERCO para o Estado de São Paulo. Gerenciamento Costeiro Integrado, $\mathrm{n}^{\mathrm{o}} 3$, ano 2: 35-37.

SOUZA, C.R. de G. 2005a. Projeto SIIGAL: Um sistema geográfico de informações geoambientais para o litoral paulista. In: AGB, SIMPÓSIO BRASILEIRO DE GEOGRAFIA FÍSICA APLICADA, 11, São Paulo, Anais, CD-ROM.

SOUZA, C.R. de G. 2005b. Projeto SIIGAL: modelo conceitual. In: ABEQUA, CONGRESSO DA ASSOCIAÇÃO BRASILEIRA DE ESTUDOS DO QUATERNÁRIO, 10, Guarapari. Anais, CD-ROM.

SOUZA, C.R. de G. 2005c. Suscetibilidade morfométrica de bacias de drenagem ao desenvolvimento de inundações em áreas costeiras. Revista Brasileira de Geomorfologia, 6(1): 45-62.

SOUZA, C.R. de G. 2006. Mapeamento de compartimentos fisiográficos de planície costeira e baixa encosta e da vegetação associada, no Litoral Norte de São Paulo. In: UGB, SIMPÓSIO NACIONAL DE GEOMORFOLOGIA, 6, Goiânia, Anais, CD-ROM.

SOUZA, C.R. de G. 2007a. Ambientes sedimentares de planície costeira e baixa-média encosta em Bertioga (SP). In: ABEQUA, CONGRESSO DA ASSOCIAÇÃO BRASILEIRA DE ESTUDOS DO QUATERNÁRIO, 11, Belém, Anais, CD-ROM.

SOUZA, C.R. de G. 2007b. Atualização do Mapa de Risco à Erosão Costeira para o Estado de São Paulo. In: ABEQUA, CONGRESSO DA ASSOCIAÇÃO BRASILEIRA DE ESTUDOS DO QUATERNÁRIO, 11, Belém, Anais, CD-ROM.

SOUZA, C.R. de G.; HOLL, M.C. \& VEDOVELLO, R. 1998. Método de mapeamento integrado do meio físico como suporte ao zoneamento ecológico-econômico da Baixada Santista, SP. In: ABGE/UFSC, SIMPÓSIO BRASILEIRO DE CARTOGRAFIA GEOTÉCNICA, 3, Florianópolis, Anais, CD-ROM.

SOUZA, C.R. de G.; LOPES, E.A. \& XAVIER, A.F. 2005. Mapa de vegetação nativa de pla- 
nície costeira e baixa-média encosta e estados de alteração, para o Litoral Norte de São Paulo (Projeto SIIGAL). In: IBt-SMA, SIMPÓSIO REGIONAL DE RECUPERAÇÃO DE ÁREAS DEGRADADAS, São Vicente, Anais, CD-ROM.

SOUZA, C.R. de G; LOPES, E. A. \& MOREIRA, M.G. 2007. Proposta de classificação de biomas de planície costeira e baixa-média encosta em Bertioga (SP). In: SEB, CONGRESSO DE ECOLOGIA DO BRASIL, 8, Caxambu, Resumos Expandidos, CD-ROM.

SOUZA, C.R. de G.; BENDAZOLI, A.; SUGIYAMA, M.; LOPES, E.A. \& KIRIZAWA, M. 1997. A relação entre o meio físico e a biota no estudo da "restinga" do Estado de São Paulo. In: ABEQUA, CONGRESSO DA ASSOCIAÇÃO BRASILEIRA DE ESTUDOS DO QUATERNÁRIO, 6, Curitiba, Resumos Expandidos, 367-372.

SOUZA, C.R. de G.; VEDOVELLO, R.; BROLLO, M.J.; TOMINAGA, L.K.; SANTORO, J. HOLL, M.C. 2001. A cartografia geotécnica no sistema integrador de informações geoambientais para a zona costeira de São Paulo (Projeto SIIGAL). In: ABGE, SIMPÓSIO BRASILEIRO DE CARTOGRAFIA GEOTÉCNICA, 4, Brasília. Anais, CD-ROM.

SOUZA, C.R. de G.; HIRUMA, S.T.; SALLUN, A.E.M.; RIBEIRO, R.R. \& AZEVEDO SOBRINHO, J.M. 2008. "Restinga": Conceitos e Empregos do Termo no Brasil e Implicações na Legislação Ambiental. Instituto Geológico - Secretaria de Meio
Ambiente do Estado de São Paulo, São Paulo, 104p. (http://www.igeologico.sp.gov. br/downloads/livros/restinga.pdf)

SOUZA, C.R. de G.; MOREIRA, M.G. \& LOPES, E.A. 2009. Coastal plain and lower-medium slope sub-biomes: a new approach based on studies developed in Bertioga (SP). Brazilian Journal of Ecology, 13( 1/2): 29-39 (http:/ www.seb-ecologia.org.br).

SUGUIO, K. \& MARTIN, L. 1976. Mecanismos de gênese das planícies sedimentares quaternárias do litoral do Estado de São Paulo. In: SBG, CONGRESSO BRASILEIRO DE GEOLOGIA, 29, Ouro Preto. Anais, 1 (2): 295-305.

SUGUIO, K. \& MARTIN, L. 1978. Mapa Geológico do Litoral de São Paulo. Escala 1:100.000. São Paulo, Secretaria de Obras e Meio Ambiente / Departamento de Águas e Energia Elétrica.

SUGUIO, K. \& PETRI, S. 1973. Stratigraphy of the Iguape-Cananéia lagoonal region sedimentary deposits, São Paulo, Brazil. Boletim do Instituto de Geociências-USP, 4: 1-20.

VEDOVELLO R. 2000. Zoneamentos Geotécnicos Aplicados à Gestão Ambiental, a partir de Unidades Básicas de Compartimentação - UBCs. Instituto de Geociências e Ciências Exatas, Universidade Estadual Paulista, Rio Claro, Tese de Doutorado, 154p.

XAVIER-DA-SILVA, J. 2001. Geoprocessamento para Análise Ambiental. Edição do Autor. Rio de Janeiro, 228p.

Endereço dos autores:

Celia Regina de Gouveia Souza - Seção de Geologia Aplicada e Ambiental, Instituto Geológico, Secretaria do Meio Ambiente do Estado de São Paulo, Avenida Miguel Stéfano, 3900, CEP 04301-903, Água Funda, São Paulo, SP. E-mail: celia@igeologico.sp.gov.br

Graciele da Costa Luna - Operator Assessoria e Análises Ambientais Ltda, Rua Eleutério, 156, CEP: 04602-030, São Paulo, SP. E-mail: graciele.geo@gmail.com 